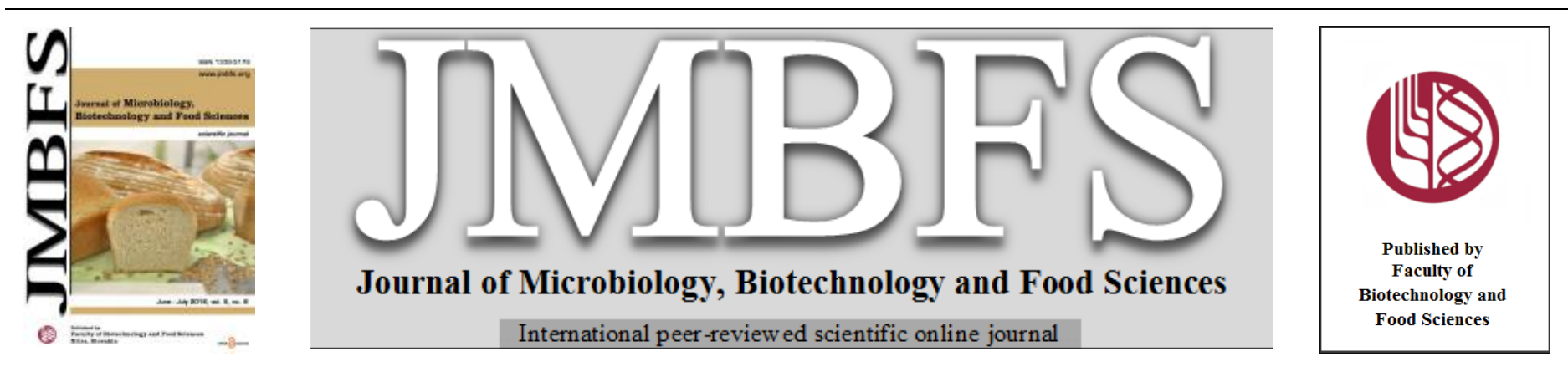

\title{
SCREENING OF ANTIMICROBIAL, CYTOTOXIC AND PESTICIDAL ACTIVITIES OF COCCINIA GRANDIS (L.) VOIGT
}

\author{
Md. Faruk Hasan", Biswanath Sikdar
}

Address(es): Md. Faruk Hasan,

Department of Genetic Engineering and Biotechnology, Faculty of Life and Earth Science, University of Rajshahi, Rajshahi-6205, Bangladesh.

*Corresponding author: faruk_geb@yahoo.com/bsikdar2004@yahoo.com

doi: 10.15414/jmbfs.2016.5.6.584-588

\section{ARTICLE INFO}

Received 10. 11. 2014

Revised 17. 2. 2016

Accepted 18. 2. 2016

Published 1. 6. 2016

Regular article

OPEN $\partial_{\text {Access }}$

\begin{abstract}
This study was undertaken to assess the antibacterial, antifungal, cytotoxic and pesticidal activities of Coccinia grandis roots extract. The antimicrobial activity was evaluated using disc diffusion method against some pathogenic microorganisms. Cytotoxicity was determined using brine shrimp lethality bioassay method. The plant extract was screened for pesticidal activity towards Sitophilus oryzae adults. Minimum inhibitory concentration (MIC) was also studied against test organisms, using serial dilution technique to determine the antibacterial potency. In antibacterial screening, large inhibition zones were observed against the tested gram-positive (Bacillus subtilis, Sarcina lutea and Stapphylococcus aureus) and gram-negative (Salmonella typhi and Shigella dysenteriae) bacteria. In antifungal screening, the extract showed moderate antifungal activities against the tested fungi (Candida albicans and Colletotrichum falcatum). In cytotoxicity activity test, $\mathrm{LC}_{50}$ (lethal concentration, 50\%) of the extract against brine shrimp nauplii was $15.00 \mu \mathrm{g} / \mathrm{ml}$. The plant extract also showed moderate pesticidal activities towards $S$. oryzae adults. These results suggested that the plant extract has significant antibacterial activity against the tested bacteria, moderate antifungal, cytotoxic and pesticidal activity towards the tested fungi, brine shrimp nauplii and $S$. oryzae adults, respectively.
\end{abstract}

Keywords: Coccinia grandis, methanol extract, antimicrobial activity, cytotoxicity, pesticidal activity

\section{INTRODUCTION}

Coccinia grandis (L.) Voigt (family of Cucurbitaceae), locally known as Telakucha, is an important medicinal plant, distributed in Indian sub-continent, Eastern Africa, and Central America. Different parts of the plant are used by humans mostly as a food crop in several countries in Australia, Asia, Caribbean, the southern United States, and Pacific Islands (Pekamwar et al., 2013). Fruits may be eaten immature and green, or mature and deep red (Hasanuzzaman $\boldsymbol{e}$ al., 2013). The young shoots and leaves may also be eaten as greens. The fruits, stems, roots and leaves of the plant are popularly used in the treatment of edema, eye diseases, carminative, hypertension, fever, anti-inflammatory, headache, typhoid, sunstroke, hypnotic, jaundice, stomach pain, anti-pyretic, mental disease, leucorrhea, alopecia, dermatitis, eczema, emetic, dysentery, scabies and blood purifier (Sivaraj et al., 2011; Abbasi et al., 2009). Phytochemical screening of Coccinia grandis revealed the presence of saponins, cardenolides, flavonoids and polyphenols that may be attributed to antibacterial activity (Sivaraj et al., 2011). The root of this plant contains resin, alkaloids, starch, fatty acids, carbonic acid, triterpenoid, saponin coccinoside, flavonoid glycoside, lupeol, $\beta$-amyrin, $\beta$-sitosterol, taraxerol (Deokate and Khadabadi, 2011).

The frequency of life-threatening infections caused by pathogenic microorganisms has increased worldwide and is becoming an important cause of morbidity and mortality in immunocompromised patients in developing countries. To overcome this problem, there is a constant need for new and effective infection fighting strategies. Therefore, there is a need to develop alternative therapeutic agents for the treatment of infectious diseases from medicinal plants (Tumpa et al., 2015). Medicinal plants continue to be used world-wide for the treatment of various diseases and have a great potential for providing novel drug leads with novel mechanism of action (Singh et al., 2012). There are many reports on Coccinia grandis plant including, antibacterial and antifungal activity of leaves extract (Bhattacharya $\boldsymbol{e t}$ al., 2010), antiplasmodial activity against the Plasmodium falciparum (Ravikumar et al., 2012), antiinflammatory activity of leaves and stem extracts (Deshpande $\boldsymbol{e t}$ al., 2011), anthelmintic activity (Tamilselvana $\boldsymbol{e t}$ al., 2011), antioxidant activity (Ashwini et al., 2012), antipyretic activity (Aggarwal et al., 2011), anticancer activity of leaves extract (Bhattacharya et al., 2011), antitussive activity of fruit extract (Pattanayak and Sunita, 2009), antiulcer activity of leaves extract (Santharam et al., 2013) and others (Kumar, 2012; Ravikumar et al., 2012). But there is no sufficient report on antimicrobial, cytotoxic and pesticidal activity on this valuable plant root extract.

The present study was designed to determine the role of methanolic extract of Coccinia grandis roots for potential antibacterial and antifungal activities against some pathogenic bacteria and fungi. The cytotoxicity and pesticidal activities of the plant extract were also determined using brine shrimp nauplii and $S$. oryzae adults, respectively.

\section{MATERIAL AND METHODS}

\section{Plant material}

Coccinia grandis plants were collected from Rajshahi University Campus, Rajshahi, Bangladesh and were identified by Md. Shahed Alam, Senior Technical Officer, Herbarium Museum, Department of Botany, University of Rajshahi, Bangladesh, where its voucher specimen was deposited for reference. Roots of these plants were used as plant material for this present investigation.

\section{Chemicals and reagents}

Methanol and DMSO (dimethyl sulfooxide) were purchased from Merck, Germany. Kanamycin was purchased from Square Pharmaceuticals Ltd., Bangladesh. Gallic acid and vincristine sulfate were purchased from Cipla Ltd., Goa, India. All the chemicals and reagents used throughout the investigation were of reagent grade.

\section{Organisms}

Antibacterial activity and MIC values were determined against six gram-positive bacteria (Bacillus cereus, Bacillus subtilis, Bacillus megaterium, Sarcina lutea, Staphylococcus aureus, and Stapphylococcus- $\beta$-haemolyticus) and seven gramnegative bacteria (Escherichia coli, Pseudomonas aeruginosa, Salmonella typhi, Shigella boydii, Shigella dysenteriae, Shigella flexneri and Shigella sonnei). Antifungal screening was carried out against seven fungi (Aspergillus fumigatus, Aspergillus flavus, Aspergillus niger, Candida albicans, Colletotrichum falcatum, 
Rhizopus oryzae and Tricophyton rubrum). Cytotoxicity was determined against brine shrimp nauplii (Artima salina). Brine shrimp nauplii were obtained by hatching brine shrimp eggs (Carolina Biological Supply Company, Burlington, NC, USA) in artificial sea water ( $3.8 \%$ sodium chloride solution) for $48 \mathrm{~h}$. These organisms were collected from the Microbiology Laboratory, Department of Microbiology and Institute of Nutrition and Food Sciences (INFS), University of Dhaka, International Centre for Diarrhoea Diseases Research Bangladesh (ICDDRB), Dhaka, Bangladesh. Pesticidal activity was tested against Sitophilus oryzae L. adult insect. The insects were collected from the "Integrated Pest Management Laboratory" Institute of Biological Sciences, University of Rajshahi, Bangladesh.

\section{Media}

Nutrient agar media (Difco laboratories) $\mathrm{pH} 7.2$, nutrient broth media (Difco Laboratories) $\mathrm{pH} 6.8$, Sabouraud dextrose agar media (Biolife Vole Monza) $\mathrm{pH}$ 5.6 and artificial seawater (3.8\% sodium chloride solution) $\mathrm{pH} 8.4$ were used for antibacterial screening, MIC determination, antifungal screening and cytotoxicity determination, respectively. A standard mixture of rice and powdered brewer's yeast in the ratio of 19:1 was used as food medium to culture $S$. oryzae.

\section{Plant material extraction and fractionation}

Collected roots of the plants were cut, air-dried powdered in a grinding machine and stored in an airtight polybag. Powdered dried roots $(400 \mathrm{~g})$ of the plant were extracted (cold) with methanol (1.25 Liter) in flat bottom conical flask, through occasional shaking and stirring for 10 days (Jeffery et al., 2000). The content was pressed through the markin cloth to get maximum amount of extract. The whole mixture was then filtered by Whatman filter paper No. 41 and the remaining filtrate was dried (Hussain et al., 2010) in vacuo to afford a blackish mass. The output extract and fraction were collected to glass vials and preserved in a refrigerator at $4^{\circ} \mathrm{C}$.

\section{Antibacterial screening}

Antibacterial screening was performed by disc diffusion method (Hussain $\boldsymbol{e t}$ al. 2010) against six gram-positive and seven gram-negative bacteria at the concentration of $300 \mu \mathrm{g} / \mathrm{disc}$, which is a qualitative to semi quantitative test. Briefly, $20 \mathrm{ml}$ quantities of nutrient agar were plated in petri dish with $0.1 \mathrm{ml}$ of a $10^{-2}$ dilution of each bacterial culture. Filter paper discs $(6 \mathrm{~mm}$ in diameter impregnated with the concentration of plant extract was placed on test organismseeded plates. Methanol was used to dissolve the extract and was completely evaporated before application on test organisms seeded plates. Blank disc impregnated with solvent methanol followed by during off was used as negative control. The activity was determined after $16 \mathrm{~h}$ of incubation at $37^{\circ} \mathrm{C}$. The diameter of zone of inhibition produced by the plant extract were then compared with the zones produced by standard antibiotic (kanamycin $30 \mu \mathrm{g} / \mathrm{disc}$ ).

\section{Determination of minimum inhibitory concentration (MIC)}

Serial tube dilution technique (Hussain et al., 2010) was used to determine MIC of the extract against six gram-positive and seven gram-negative bacteria. The plant extract $(1.0 \mathrm{mg}$ ) was dissolved in $2 \mathrm{ml}$ distilled water ( 2 drops tween-80 was added to facilitate dissolution) to obtain stock solution. After preparing the suspensions of test organisms $\left(10^{7}\right.$ organisms per $\left.\mathrm{ml}\right), 1$ drop of suspension $(20 \mu \mathrm{l})$ was added to each broth dilution. After $16 \mathrm{~h}$ incubation at $37^{\circ} \mathrm{C}$, the tubes were then examined for the growth. The MIC values of the extract were taken as the lowest concentration that showed no growth. Growth was observed in those tubes where the concentration of the extract was below the inhibitory level and the broth medium was observed to be turbid (cloudy). Distilled water with 2 drops of tween- 80 and kanamycin were used as negative and positive control, respectively.

\section{Antifungal screening}

The antifungal activity of the extract was tested by disc diffusion method (Hussain et al., 2010) against the five pathogenic fungi at the concentrations of $300 \mu \mathrm{g} /$ disc for each. Here, $20 \mathrm{ml}$ quantities of nutrient agar were plated in petri dish with $0.1 \mathrm{ml}$ of a $10^{-2}$ dilution of each bacterial culture. Filter paper discs $(6$ $\mathrm{mm}$ in diameter) impregnated with the concentration of plant extract was placed on test organism-seeded plates. Methanol was used to dissolve the extract and was completely evaporated before application on test organisms seeded plates. Blank disc impregnated with solvent methanol followed by during off was used as negative control. The activity was determined after $72 \mathrm{~h}$ of incubation at room temperature $\left(32^{\circ} \mathrm{C}\right)$. The diameter of zone of inhibition produced by the extract were then compared with the zones produced by standard antibiotic (kanamycin $30 \mu \mathrm{g} / \mathrm{disc})$.

\section{Cytotoxicity bioassay}

Cytotoxicity of $C$. grandis roots was screened against Artemia salina in a one day in vivo according to published protocols (Rahman et al., 2010). Brine shrimp nauplii were obtained by hatching brine shrimp eggs in artificial sea water $(3.8 \%$ sodium chloride solution) for $48 \mathrm{~h}$ in $25^{\circ} \mathrm{C}$. Dissolution for extract was performed in artificial sea water using DMSO. Serially diluted test solutions $(0.5,1,2,5,10$, 20 and $40 \mu \mathrm{g} / \mathrm{ml}$ ) were added to the sea water $(5 \mathrm{ml})$ containing 10 nauplii. After incubation for $24 \mathrm{~h}$ at $25^{\circ} \mathrm{C}$, the numbers of survivors was counted. From this data, lethal concentration ( $\left.\mathrm{LC}_{50}\right)$ and $95 \%$ confidence intervals of the test samples were calculated using probit analysis method described by Finney (Finney, 1971). Each sample was used in triplicate for the determination of the $\mathrm{LC}_{50}(50 \%$ lethal concentrations, $\mu \mathrm{g} / \mathrm{ml}$ ). Gallic acid and vincristine sulfate were used as standards in this bioassay.

\section{Assessment of pesticidal activity}

Pesticidal activity of $C$. grandis root extract was assessed against $S$. oryzae adults as previously described (Roy et al., 2005). The mortality test was performed at the concentrations of $100,50,25$ and $12 \mathrm{mg} / \mathrm{ml}$. $1 \mathrm{ml}$ solution of each doses were dropped onto the petri dishes (6 cm diameter), spread and then air dried for five minutes. Ten adult insects (10-12 days old) were release into each petri dish, kept in room temperature and mortality (\%) were recorded at 24, 48 and $72 \mathrm{~h}$ after treatment. For determining repellency test, required amount of extract was dissolved in methanol to obtain the concentrations as $100,50,25$ and $12 \mathrm{mg} / \mathrm{ml}$. Filter papers (Whatman No. 40, diameter $9 \mathrm{~cm}$ ) were cut into two half, and $1 \mathrm{ml}$ solution of each dose was applied to each half uniformly with a dropper. The treated half of the papers were then air-dried at attached with the untreated half with a cello-tape at middle and paper was then placed on the petri dish. Ten adult insects were release in treated papers and petri dishes were placed in the laboratory at room temperature. The insects present on each half of the paper strip were counted at 24,48 and $72 \mathrm{~h}$ after treatment.

\section{Statistical analysis}

The experimental results are presented as mean for three triplicates for studied parameters. The median lethal concentration $\left(\mathrm{LC}_{50}\right)$ and $95 \%$ confidence intervals of the test samples were calculated using probit analysis method described by Finney (Finney, 1971).

\section{RESULTS AND DISCUSSION}

\section{Antibacterial activity}

The results representing antibacterial activity of methanol extract of roots are presented in Table 1. The highest inhibition zones of root extract were $26.0 \mathrm{~mm}$ diameter found against $B$. subtilis, $S$. aureus and $S$. lutea (gram-positive) followed by $25.0 \mathrm{~mm}$ diameter against $S$. typhi and $S$. dysenteriae (gramnegative) at the concentration of $300 \mu \mathrm{g} /$ disc. The lowest activity of plant extract was $16.0 \mathrm{~mm}$ diameter of zone inhibition observed against Bacillus cereus at the concentration of $300 \mu \mathrm{g} / \mathrm{disc}$. But, the extract found no inhibition zone against $S$. sonnei and $S$. flexneri at the concentration of $300 \mu \mathrm{g} / \mathrm{disc}$. Negative control exhibited no zone of inhibition against all the organisms. In comparison to reference standard antibiotic (kanamycin, $30 \mu \mathrm{g} / \mathrm{disc}$ ), the methanol extract of root exhibited significant antibacterial activities at the concentration of 300 $\mu \mathrm{g} / \mathrm{disc}$ against almost all of the organisms tested (Table 1). Bhattacharya $\boldsymbol{e t}$ al. (2010) evaluated the aqueous extract of leaves of Coccinia grandis for antibacterial activity against Shigella flexneri NICED, Bacillus subtilis, Escherichia coli, Salmonella choleraesuis, Shigella dysenteries, and Shigella flexneri. Ethanolic extract of Coccinia grandis leaf showed high antibacterial activity against $S$. pigeons, E. coli, B. ceres, K. pneumonia and S. aureus (Sivaraj et al., 2011). Hasanuzzaman et al., (2013) reported $12 \mathrm{~mm}$ of zone of inhibition of Coccinia grandis root extract against Staphylococcus aureus. Previous studies on antibacterial activity of fruits, leaves and stem of Coccinia grandis (Aggarwal et al., 2011; Hussain et al., 2010) have also detected the significant activity of methanol extract against different pathogenic bacteria providing support to the fact that methanol is a better solvent for extraction and screening of phytochemicals having antimicrobial activity. 
Table 1 Antibacterial activities of methanol extract of Coccinia grandis roots.

\begin{tabular}{lcc}
\hline \multirow{2}{*}{ Test organisms } & \multicolumn{2}{c}{ Diameter of zone of inhibition $(\mathbf{i n} \mathbf{~ m m})$} \\
\cline { 2 - 3 } & $\begin{array}{c}\text { Methanol extract } \\
(\mathbf{3 0 0} \boldsymbol{\mu} \mathbf{g} / \mathbf{d i s c})\end{array}$ & $\begin{array}{c}\text { Kanamycin } \\
\mathbf{( 3 0} \boldsymbol{\mu} \mathbf{g} / \mathbf{d i s c})\end{array}$ \\
\hline Gram-positive & 16 & 24 \\
\hline Bacillus cereus & 26 & 31 \\
Bacillus subtilis & 23 & 32 \\
Bacillus megaterium & 26 & 26 \\
Sarcina lutea & 26 & 33 \\
Stapphylococcus aureus & 18 & 28 \\
Stapphylococcus- $\beta$ - & & \\
haemolyticus & 22 & 29 \\
\hline Gram-negative & 19 & 27 \\
\hline Escherichia coli & 25 & 31 \\
Pseudomonas aeruginosa & 23 & 31 \\
Salmonella typhi & 25 & 32 \\
Shigella boydii & 0.0 & 21 \\
Shigella dysenteriae & 0.0 & 19 \\
Shigella flexneri & Shigella sonnei &
\end{tabular}

Note: Data are represented in the form of mean of three tested of the standar groups.

\section{Minimum inhibitory concentration (MIC) measurement}

The Minimum inhibitory concentration (MIC) values of the extract against tested bacteria were shown in Table 2 . The MIC values were 64, 16, 32, 16, 16, 64, 32, $64,32,64,32,64$ and $128 \mu \mathrm{g} / \mathrm{ml}$ respectively, against the tested organisms (six gram positive and seven gram negative). The MIC values against the tested gram positive bacteria ranged from 16 to $64 \mu \mathrm{g} / \mathrm{ml}$ and against gram negative bacteria from 32 to $128 \mu \mathrm{g} / \mathrm{ml}$. Negative controls exhibited no inhibition against all the organisms. The standard antibiotic (kanamycin) had MIC values varying 4 to16 $\mu \mathrm{g} / \mathrm{ml}$ against the tested organisms. Antibacterial potency of the plant extract against these bacteria expressed in MIC values indicated that the plant extract is more effective against gram-positive bacteria than gram negative bacteria Sivaraj et al., (2011) reported with $31.25 \mu \mathrm{g} / \mathrm{ml}$ MIC values of Coccinia grandis leave extract against Stapphylococcus aureus. Bhattacharya et al. (2010) showed $1000-1750 \mu \mathrm{g} / \mathrm{ml}$ of MIC values of Coccinia grandis leaves extract against some gram positive and gram negative bacteria. Hasan and Rahman, 2011; Saikot et al., (2012); Khan et al., (2013) reported similar MIC values for different plant extracts which supported our present findings.

Table 2 Minimum inhibitory concentration (MIC) of methanol extract of Coccinia grandis roots.

\begin{tabular}{lcc}
\hline Test organisms & $\begin{array}{c}\text { Methanol extract } \\
(\mu \mathbf{g} / \mathbf{m l})\end{array}$ & $\begin{array}{c}\text { Kanamycin } \\
(\mu \mathbf{g} / \mathbf{m l})\end{array}$ \\
\hline Gram-positive & 64 & 16 \\
\hline Bacillus cereus & 16 & 4 \\
Bacillus subtilis & 32 & 4 \\
Bacillus megaterium & 16 & 4 \\
Sarcina lutea & 16 & 8 \\
Stapphylococcus aureus & 64 & 8 \\
Stapphylococcus- $\beta$-haemolyticus & & 8 \\
\hline Gram-negative & 32 & 4 \\
\hline Escherichia coli & 64 & 4 \\
Pseudomonas aeruginosa & 32 & 8 \\
Salmonella typhi & 64 & 8 \\
Shigella boydii & 32 & 8 \\
Shigella dysenteriae & 64 & 16 \\
Shigella flexneri & 128 & \\
Shigella sonnei & & \\
\hline Note: Data are represented in the form & & \\
\hline
\end{tabular}

Note: Data are represented in the form of mean of three tested of the standard groups.

\section{Antifungal activity}

The antifungal activities of methanol extract of the plant root $(300 \mu \mathrm{g} / \mathrm{disc})$ and standard kanamycin $(30 \mu \mathrm{g} / \mathrm{disc})$ were determined against seven pathogenic fungi (Table 3). The highest activity was $19.0 \mathrm{~mm}$ diameter of zone inhibition observed against $C$. albicans and C. falcatum followed by $17.0 \mathrm{~mm}$ diameter of zone inhibition against $A$. niger at the concentration of $300 \mu \mathrm{g} /$ disc. The lowest activity was $7.0 \mathrm{~mm}$ diameter of zone inhibition found against Aspergillus fumigatus at the concentration of $300 \mu \mathrm{g} / \mathrm{disc}$. The lowest activity was $6 \mathrm{~mm}$ diameter of zone inhibition found against A. fumigatus at the concentration of $300 \mu \mathrm{g} / \mathrm{disc}$. The plant extract showed no inhibition zone against $A$. flavus and $T$. rubrum. Negative control exhibited no zone of inhibition against all the organisms. In comparison to reference standard antibiotic (kanamycin, 30 $\mu \mathrm{g} / \mathrm{disc}$ ), the methanol extract of root exhibited significant antifungal activities at the concentration of $300 \mu \mathrm{g} / \mathrm{disc}$ against almost all of the organisms tested (Table 3). Bhattacharya et al., (2010) evaluated the antifungal activity of the Coccinia grandis leaves extract against the Candida albicans-II, Candida tropicalis, Aspergillus niger, Saccharomyces cerevisiae, Candida tropicalis II, Cryptococcus neoformans and Candida albicans ATCC. Satheesh and Murugan (2011) reported that $C$. grandis leaves have a strong inhibition activity against pathogenic fungus $C$. albicans, $M$. indicus, $P$. notatum, A. flanus and $C$. neoformans. Previous studies on antifungal activity of different plants crude extracts (Hasanuzzaman et al., 2013; Khan et al., 2013; Hasan et al., 2009) have also detected the significant activity against some pathogenic fungi which support our present findings.

Table 3 Antifungal activities of methanol extract of $C$. grandis roots.

\begin{tabular}{lcc}
\hline \multirow{2}{*}{ Test organisms } & \multicolumn{2}{c}{ Diameter of zone of inhibition (in mm) } \\
\cline { 2 - 3 } & $\begin{array}{c}\text { Methanol extract }(\mathbf{3 0 0} \boldsymbol{\mu g} / \\
\text { disc) }\end{array}$ & $\begin{array}{c}\text { Kanamycin } \\
(\mathbf{3 0} \boldsymbol{\mu g} / \mathbf{d i s c})\end{array}$ \\
\hline Aspergillus fumigatus & 7 & 19 \\
Aspergillus flavus & 0.0 & 17 \\
Aspergillus niger & 17 & 23 \\
Candida albicans & 19 & 24 \\
Colletotrichum & 19 & 22 \\
falcatum & 15 & 21 \\
Rizopus oryzae & 0.0 & 19 \\
Tricophyton rubrum & & \\
\hline
\end{tabular}

Note: Data are represented in the form of mean of three tested of the standard groups.

\section{Cytotoxicity bioassay}

The $\mathrm{LC}_{50}$ values of the brine shrimp lethality bioassay obtained for root extract of the plant and that of the positive controls gallic acid and vincristine sulfate, has been presented in Table 4 . The extract showed significant cytotoxicity against brine shrimp nauplii. The $\mathrm{LC}_{50}$ value of the plant extract was $15.00 \mu \mathrm{g} / \mathrm{ml}$, whereas the cytotoxicity of standard gallic acid and vincristine sulfate $\mathrm{LC}_{50}$ values were 7.50 and $2.90 \mu \mathrm{g} / \mathrm{ml}$ respectively. No mortality was found in the control group. Hasanuzzaman et al., (2013) showed significant cytotoxicity with $\mathrm{LC}_{50}$ of $2.49 \mu \mathrm{g} / \mathrm{ml}$ in ethanolic extract of $C$. grandis roots. Saikot et al., (2012) showed cytotoxicity against brine shrimp nauplii with $\mathrm{LC}_{50}$ of $7.06 \mu \mathrm{g} / \mathrm{ml}$ in acetone extract of Abroma augusta leaves. Hasan and Rahman, (2011) reported cytotoxicity with $\mathrm{LC}_{50}$ of $35.45 \mu \mathrm{g} / \mathrm{ml}$ in ethanol extract of Polygonum hydropipper stem. These cytotoxicity results support our present findings.

Table 4 Cytotoxic activity of methanol extract of Coccinia grandis roots on brine shrimp nauplii.

\begin{tabular}{lcccc}
\hline Samples & $\mathbf{L C}_{\mathbf{5 0}}(\boldsymbol{\mu g} / \mathbf{m l})$ & $\mathbf{9 5 \%}$ confidence limits $(\boldsymbol{\mu g} / \mathbf{m l})$ & Regeneration equation & $\mathbf{X}^{\mathbf{2}}$ value \\
\hline Plant extract & 15.00 & $10.5-25.00$ & $\mathrm{Y}=2.65+2.01 \mathrm{X}$ & 1.71 \\
Gallic acid & 7.50 & $5.10-13.50$ & $\mathrm{Y}=3.83+1.52 \mathrm{X}$ & 1.25 \\
Vincristine sulfate & 2.90 & $1.34-5.55$ & $\mathrm{Y}=2.16+1.98 \mathrm{X}$ & 0.61 \\
\hline
\end{tabular}

Note: $\mathrm{LC}_{50}$ values, confidence limits, regeneration equations and $\mathrm{X}^{2}$ values were calculated by probit analysis. 


\section{Assessment of pesticidal activity}

In the present investigation, pesticidal activity of methanol extract of the plant root against Sitophilus oryzae has been determined. The mortality (\%) and repellency $(\%)$ of $S$. oryzae adults in different concentrations, at different exposure periods has been given in Fig. 1 and 2. The highest percentage of mortality was $73.3 \%$ found at the concentration of $100 \mathrm{mg} / \mathrm{ml}$ after 72 hours of treatment, followed by $66.6 \%$ at the same concentrations after 48 hours. On the other hand, no mortality $(0.0 \%)$ was observed in the concentration of $12 \mathrm{mg} / \mathrm{ml}$ after 24 hours (Fig. 1). Similarly, the highest percentage of repellency was $80.0 \%$ observed at the concentration of $100 \mathrm{mg} / \mathrm{ml}$ after 72 hours followed by $73.3 \%$ at the same concentration after 48 hours. On the left hand, the lowest percentage of repellency was $6.6 \%$ found at the concentration of $12 \mathrm{mg} / \mathrm{ml}$ after 24 hours (Fig 2). The control group had no mortality and repellency; therefore, it has not been presented. Mobki et al., (2014) reported with $83.3 \%$ mortality and 95\% repellency of Tribolium castaneum larvae using garlic extract. Roy et al., (2005) reported with $56.71 \%$ mortality and $55.34 \%$ repellency of Sitiphilus oryzae using Blumea lacera plant extract. Rahman et al., (2007) reported with highest $34.0 \%$ mortality and $22.43 \%$ repellency in Sapindus mukorossi fruits extract against Sitiphilus oryzae adult insect. These results was similar to our present findings.

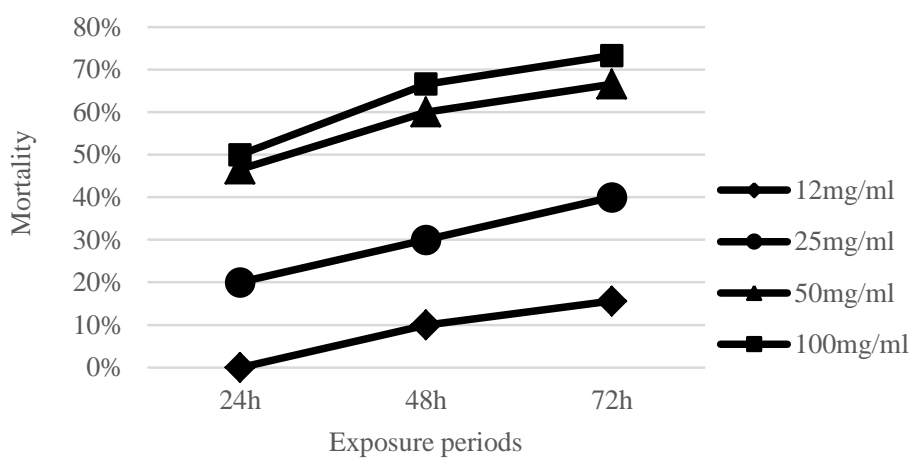

Figure 1 Regression line of mortality $(\%)$ on different doses $(\mathrm{mg} / \mathrm{ml})$ of root extract of methanol on $S$. oryzae at different exposure periods.

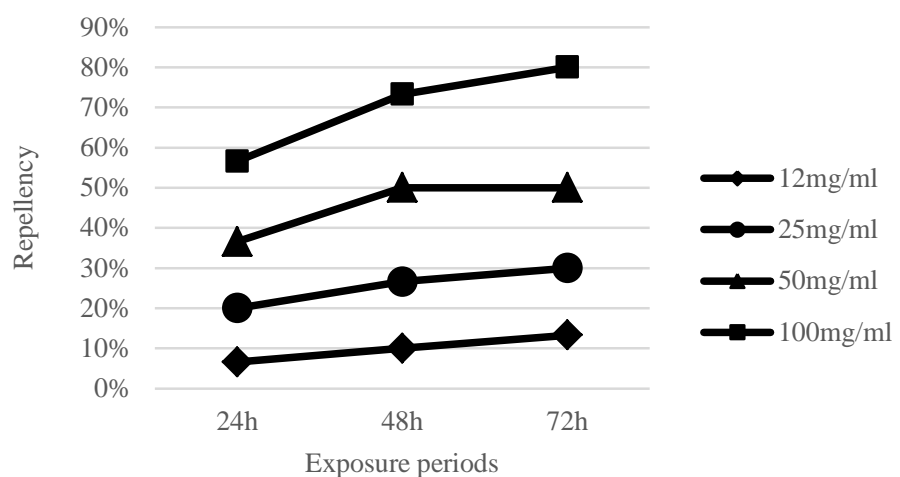

Figure 2 Regression line of repellency $(\%)$ on different doses $(\mathrm{mg} / \mathrm{ml})$ of root extract of methanol on $\mathrm{S}$. oryzae at different exposure periods

\section{CONCLUSION}

The results observed in the present study demonstrated that Coccinia grandis roots have promising antimicrobial $(300 \mu \mathrm{g} / \mathrm{disc})$, cytotoxic $(15.00 \mu \mathrm{g} / \mathrm{ml})$ and pesticidal $(100 \mathrm{mg} / \mathrm{ml})$ activities. These antimicrobial, cytotoxic and pesticidal activities are probably first reported for the methanol extract of roots of Coccinia grandis. Further, remarkable antimicrobial, cytotoxic and pesticidal activities found by the experiments support the claims of traditional medicine. The present findings can be source of antibiotic substances for possible treatment of microbial infections. The cytotoxicity and pesticidal results revealed that the Coccinia grandis roots extract might be considered as a moderate toxic. However, to isolate these active phytochemicals and determine their activities are in progress.

Acknowledgments: The authors wish to thanks International Centre for Diarrhoea Diseases Research Bangladesh (ICDDRB), Dhaka, Microbiology Laboratory, Department of Microbiology and Institute of Nutrition and Food Sciences (INFS), University of Dhaka, Integrated Pest Management Laboratory, Institute of Biological Sciences, University of Rajshahi, Bangladesh. for providing all the organisms support to carry the whole research work.

\section{REFERENCES}

ABBASI, A.M., KHAN, M.A., AHMAD, M., ZAFAR, M., KHAN, H. MUHAMMAD, N., SULTANA, S. 2009. Medicinal plants used for the treatment of jaundice and hepatitis based on socio-economic documentation. African Journal of Biotechnology, 8 (8), 1643-1650.

AGGARWAL, A.S., SURAALKAR, U.R., CHAUDHARI, S.G., DESPANDE S.V., GARUD, A.A., TALELE, S.G. 2011. Analgesic and antipyretic activity of methanolic extract of Coccinia grandis L. leaves in experimental animals Research Journal of Pharmaceutical, Biological and Chemical Sciences, 2, 175 182

ASHWINI, M., NISHA, L., BOLE, S., VEDAMURTHY, A.B., BALU, S. 2012 In vitro antioxidant and antiinflammatory activity of Coccinia grandis International Journal of Pharmacy and Pharmaceutical Sciences, 4(3), 239-242. BHATTACHARYA, B., PAL, P., LALEE, A., MAL, D.K. SAMANTA, A 2010. In vitro evaluation of antifungal and antibacterial activities of the plant Coccinia grandis (L.) Voigt. (Family-Cucurbitaceae). Journal of Phytology, 2(11), 52-57. BHATTACHARYA, B., PAL, P., LALEE, A., MAL, D.K., SAMANTA, A. 2011. In-vivo and in-vitro anticancer activity of Coccinia grandis (L.) Voigt. (Family: Cucurbitaceae) on Swiss albino mice. Journal of Pharmacy Research, 4(3), 567-569.

DEOKATE, U.A., KHADABADI, S.S. 2011. Pharmacology and photochemistry of Coccinia indica.Journal of Pharmacognosy and Phytotherapy, 3(11), 155 159.http://dx.doi.org/10.5897/JPP11.005

DESHPANDE, S.V., PATIL, M.J., DASWADKAR, S.C., SURALKAR, U., AGARWAL, A. 2011. A study on anti-inflammatory activity of the leaf and stem extract of Coccinia grandis. Viogt. International Journal of Applied Biology and Pharmaceutical Technology, 2(3), 247-250.

FINNEY, D.J. 1971. Probit Analysis. 3rd ed. University press. Cambridge, UK 333 p., ISBN-10: 0521135907

HASAN, M.F., DAS, R., KHAN, A., HOSSAIN, M.S., RAHMAN, M. 2009. The Determination of Antibacterial and Antifungal Activities of Polygonum hydropiper (L.) Root Extract. Advances in Biological Research, 3 (1-2), 53-56. HASAN, M.F., RAHMAN, M.M. 2011. Screening of antibacterial, antifungal and cytotoxic activities of Polygonum hydropiper L. stem extracts. International Journal of Biosciences, 6 (1), 47-53.

HASANUZZAMAN, M., SAYEED, M.S.B., ISLAM, M.S., SARWAR, M.S., MOGHAL, M.M.R., AHMED, J.U., ISLAM, M.S. 2013. Preliminary Antimicrobial activity and Cytotoxicity of plant extracts (roots) of Coccinia grandis (Family: Cucurbitaceae). International Journal of Pharmaceutical Sciences and Research, 4(4), 1466-1468.

HUSSAIN, A., WAHAB, S., ZARIN, I., HUSSAIN, M.D.S. 2010. Antibacterial Activity of the Leaves of Coccinia indica (W. and A) Wof India. Advances in Biological Research, 4 (5), 241-248.

JEFFERY, G.H., BASSETT, J., MENDHAM, J., DENNEY R.C 2000. Vogel's Textbook of Quantitative Chemical Analysis. 5th ed. Longman Group UK Ltd. England, 161 p. ISBN 0-476-21517-8.

KHAN, S., ULLAH, F., MAHMOOD, T. 2013. In vitro antimicrobial and cytotoxic activity of Tamarix dioica Roxb. Leaves. Turkish Journal of Biology, 37, 329-335. http://dx.doi.org/10.3906/biy-1204-18

KUMAR, A. 2012. A review of hepatoprotective herbal drugs. International Journal of Research in Pharmacy and Chemistry, 2, 92-102.

MOBKI, M., SAFAVI, S.A., SAFARALIZADEH, M.H., PANAHI, O. 2014 Toxicity and repellency of garlic (Allium sativum L.) extract grown in Iran against Tribolium castaneum (Herbst) larvae and adults. 47 (1), 59-68 http://dx.doi.org/10.1080/03235408.2013.802896

PATTANAYAK, S.P., SUNITA, P. 2009. In vivo antitussive activity of Coccinia grandis against irritant aerosol and sulfur dioxide-induced cough model in

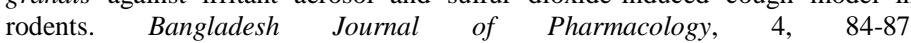
http://dx.doi.org/10.3329/bjp.v4i2.1537

PEKAMWAR S.S., KALYANKAR, T.M., KOKATE, S.S. 2013 Pharmacological Activities of Coccinia Grandis: Review. Journal of Applied

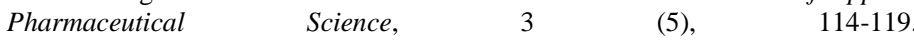
http://dx.doi.org/10.7324/JAPS.2013.3522

RAHMAN, S.S., RAHMAN, M.M., KHAN, M.M.R., BEGUM, S.A., ROY, B., SHAHED, S.M.F. 2007. Ethanolic extract of melgota (Macaranga postulata) for repellency, insecticidal activity against rice weevil (Sitophilus oryzae). African Journal of Biotechnology, 6 (4), 379-383.

RAVIKUMAR, S., INBANESON, S.J., SUGANTHI, P. 2012. In vitro antiplasmodial activity of ethanolic extracts of South Indian Medicinal plants against Plasmodium falciparum. Asian Pacific Journal of Tropical Disease, 2(3) 180-183. http://dx.doi.org/10.1016/S2222-1808(12)60043-7

ROY, B., AMIN, R., UDDIN, M.N., ISLAM, A.T.M.S., ISLAM, M.J., HALDER, B.C. 2005. Leaf Extracts of Shiyalmutra (Blumea lacera Dc.) as Botanical Insecticides Against Lesser Grain Borer and Rice Weevil. Journal of Biological Sciences, 5, 201-204. http://dx.doi.org/10.3923/jbs.2005.201.204 SAIKOT, F.K., ALAM KHAN, HASAN. M.F. 2012. Antimicrobial and cytotoxic activities of Abroma augusta Lnn. Leaves extract. Asian Pacific Journal of Tropical Biomedicine, 2 (Sup. 3), 1418-1422. http://dx.doi.org/10.1016/S2221-1691(12)60429-8 
SANTHARAM, B., DIVYA V. V., THIRUPATHI A.T. 2013. Anti-ulcer activity of ethanolic, aqueous and total aqueous extracts of Coccinia grandis linn. Voigt in pyloric ligature induced ulcers in albino RATS. International Journal of Pharmacy and Pharmaceutical Sciences, 5(4), 104-106.

SATHEESH, S.L., MURUGAN, K. 2011. Antimicrobial activity of protease inhibitor from leaves of Coccinia grandis (L.) Voigt. Indian Journal of Experimental Biology, 49, 366-374.

SINGH, R., DAR, S.A., SHARMA, P. 2012. Antibacterial activity and toxicological evaluation of semi purified hexane extract of Urtica dioica leaves. Research Journal of Medicinal Plants, 6(2), 123-135. http://dx.doi.org/10.3923/rjmp.2012.123.135

SIVARAJ, A., PREETHI JENIFA, B., KAVITHA, M., INBASEKAR, P. SENTHILKUMAR, B., TAMILSELVAN, N.P. 2011. Antibacterial activity of Coccinia grandis leaf extract in selective bacterial strains. Journal of Applied Pharmaceutical Science, 01 (07), 120-123.

TAMILSELVANA, N., THIRUMALAIA, T., ELUMALAIA, E.K., BALAJIB, R., DAVIDB, E. 2011. Pharmacognosy of Coccinia grandis: a review. Asian Pacific Journal of Tropical Biomedicine, 1(2), S299- 302 http://dx.doi.org/10.1016/S2221-1691(11) 60176-7

TUMPA, S.I, HOSSAIN, M.I., ISHIKA, T. 2015. Antimicrobial activities of Psidium guajava, Carica papaya and Mangifera indica against some gram positive and gram negative bacteria. Journal of Pharmacognosy and Phytochemistry, 3(6), 125-129. 